\title{
Trogoxylyctus australiensis a new genus and species of Trogoxylini Lesne, 1921 (Coleoptera, Bostrichidae, Lyctinae) from Australia
}

\author{
Piotr Węgrzynowicz ${ }^{1}$, Jerzy Borowski ${ }^{2}$ \\ ${ }^{1}$ Institute of Forest Sciences, University of Łódź, Branch in Tomaszów Mazowiecki, ul. Konstytucji \\ 3 Maja 65/67, 97-200 Tomaszów Mazowiecki, Poland \\ ${ }^{2}$ Department of Forest Protection and Ecology, University of Life Sciences, SGGW, ul. \\ Nowoursynowska 159/34, 02-776 Warsaw, Poland \\ email address: piotr.wegrzynowicz@gmail.com; jerzy_borowski@sggw.pl
}

Keywords: Coleoptera, Bostrichidae, Lyctinae, Trogoxylini, Trogoxylyctus australiensis, new genus, new species, Australia, key for the identification.

\begin{abstract}
New species representing a new genus of Bostrichidae Trogoxylyctus australiensis gen. nov., sp. nov. is desribed from Australia. In the general outlook it resembles the African genus Lycthoplites Lesne of the tribe Lyctini, but morphological similarity is in this case evidently a result of convergence. A key to the identification of know Australian representatives of Trogloxylini is given.
\end{abstract}

\section{INTRODUCTION}

The tribe Trogoxylini Lesne, 1921 contains 25 known species classified in 5 genera: Tristaria Reitter, 1878, Phyllyctus Lesne, 1911, Cephalotoma Lesne, 1911, Lyctopsis Lesne, 1911 and Trogoxylon LeConte, 1862 (Borowski \& Węgrzynowicz 2012). Representatives of these genera occur on all continents. Only three species of the Trogoxylini - Tristaria grouvellei Reitter, 1878, Trogoxylon punctipenne (Fauvel, 1904) and Trogoxylon ypsilon Lesne, 1937 - have been hitherto known to inhabit Australian Region (Borowski \& Węgrzynowicz 2007; Borowski \& Węgrzynowicz 2012). Lawrence \& Ślipiński (2013) have published the key to the identification of Australian genera of Lyctinae.

In the course of revision of the Bostrichidae in the Natural History Museum (HNHM) in Budapest we found two specimens whose general outlook, and especially structure of pronotum, resembled Lycthoplites armatus Lesne, 1935 - a species of the tribe Lyctini known from tropical Africa. Analysis of morphological characters have shown, however, that the Australian species belongs to the Trogoxylini, even though being so different from all the hitherto known genera that the description of new species and erection of new genus was necessary. This is done below.

\section{RESULTS - DIAGNOSIS, DESCRIPTION, REMARKS and KEYS}

Trogoxylyctus gen. nov.

Gender: masculine.

Type species: Trogoxylyctus australiensis sp. nov., here designated

2.1. Diagnosis. Strongly swollen femora and distinct pronotal carinae make the attribution of the new genus to Trogloxylini straightforward, but equally straightforward is its distinction from all known representatives of the tribe: prosternal process, broad, flat and conspicuously widened apically in other genera, is here very narrow and pointed. Also pronotal structure (all angles sharp and protruding, two prominent carinulae in anterior part) is distinctive.

2.2. Description. Antennae 11-jointed, with two-jointed club (Fig. 6). Eyes large, strongly convex, distinctly protruding from head outline (Figs. 2, 3). Mandibulae with one sharp preapical denticle. Labrum markedly emarginated at middle (Fig. 3). Epistome poorly separated, distinctly narrower than front, both epistome and lower part of front laterally bordered with almost vertically elevated 
lamellar ridges (Fig. 3). All pronotal margins very well marked, entirely visible from above. Angles prominent, sharp. Anterior margin slightly wavily emarginated, with, to both sides of emargination, pair of upward protruding costulae not reaching middle of pronotum. Anterior part of pronotum, between costulae and lateral margins, with fine and sparse granules (Fig. 4). Scutellum small, transverse, clearly visible. Humeral tubercles well marked. Elytra narrowly ovately elongated, glabrous, inconspicuously punctulated, distinctly rounded apically (Fig. 5). Ventral surface lustrous, almost glabrous. Prosternum glabrous medially, shallowly punctured on sides. Prosternal process strongly narrowed towards apex where it appears as narrow sharp lamella (Fig. 11). Mesosternum finely punctulated and very shortly, inconspicuously pubescent. Metasternum and abdomen almost smooth. First sternite as long as the following two together. Procoxae about as long as wide. Femora strongly swollen at middle, excavated on ventral side to receive tibiae (these excavations are deepest at base of tibiae becoming shallower towards femoral midlength where they vanish). Protibiae slightly widened to apices (Fig. 7), meso- and metatibiae of similar width all along. Protibial apices with broadly triangular thorn on outer margin and curved spur reaching almost to the end of first visible tarsomere (Fig. 9). Ovipositor almost as long as pronotum and elytra together.

Trogoxylyctus australiensis sp. nov. (Figs. 1-7, 11)

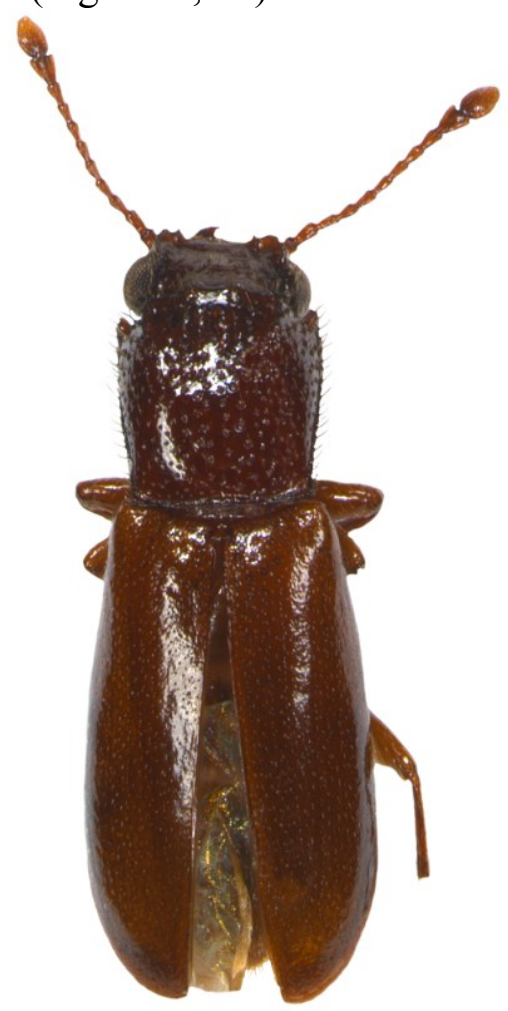

Fig. 1. Trogoxylyctus australiensis gen. nov., sp. nov., holotype

Type material. Holotype, female: "Australia, N.T., Near Phillip Creek on Stuart Highway, 331m, S19¹8'343', E134¹1'04', Hungarian Entomological Expedition in Australia, leg. G. Hangay, I. Rozner, A. Podlussány, 2.XI.2000" (HNHM, Budapest). Paratype, female: “Australia, N.T., Near Elsey Creek on Stuart Highway, (UV light), S15¹4'119', E13306'749', Hungarian Entomological Expedition in Australia, leg. G. Hangay, I. Rozner, A. Podlussány, 3.XI.2000" (Jerzy Borowski's coll.).

Description. Length 2.3-2.9 mm. Body elongated, shining, yellowish-brown, pronotum and head darker reddish-brown (Fig. 1). Antennomeres elongated, slightly pubescent (Fig. 6). Last joint of club ovate, distinctly longer than wide and somewhat longer than penultimate (Fig. 6). Front and narrow epistome join into almost uniform flat surface, separated from one another with only fine inconspicuous line (Fig. 3). Sides of front and epistome bordered with almost vertically elevated lamellar ridges. Front at middle with several fine granules and punctures bearing short setulae (Fig. 
2). Anterior part of pronotum with erect pubescence, posterior almost glabrous (Fig. 4). Costulae running from anterior margin finely crenulated. Pronotal sides uniformly divergent from basal angles anterad, with maximum width at apical angles. Basal angles slightly protruding outwards. Surface not mocrosculptured, puncturation sparse, shallow, coarser at middle than on sides. Lower margin of pronotum almost straight (Fig. 4). Scutellum subtrapezoidal (Fig. 5). Elytra glabrous, widest at midlength. Punctures very fine and shallow, inconspicuous, tending to form longitudinal rows on sides (Fig. 5). Sides of prosternum densely, shallowly, in posterior part confluently punctured. Metasternum smooth. Abdominal setulae sparse, very short, recumbent. Protibiae widened towards apices (Fig. 7), more conspicuously pubescent than other pairs.

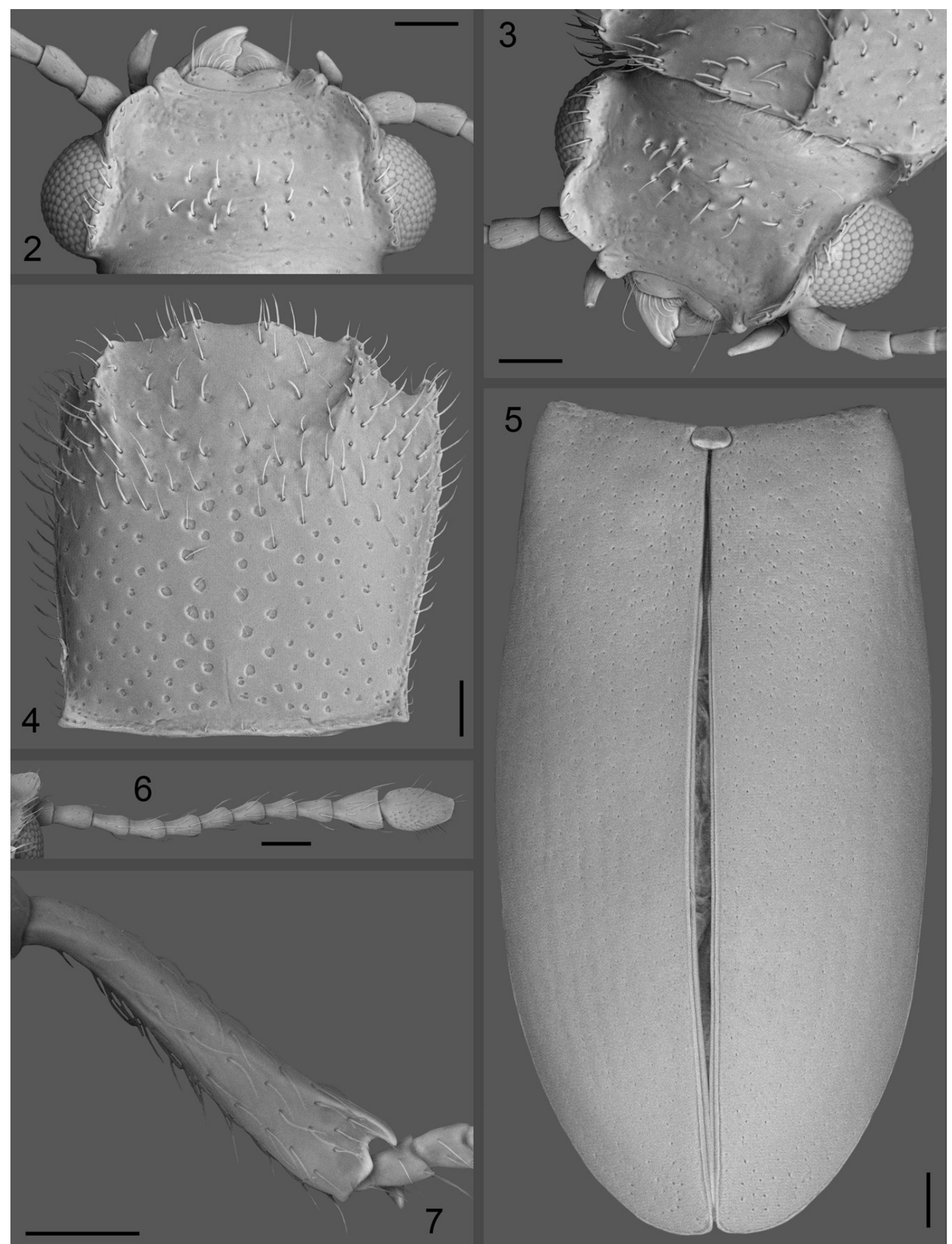

Figs. 2-7. Trogoxylyctus australiensis gen. nov., sp. nov.: (2) head; (3) head, semilateral; (4) pronotum; (5) elytra; (6) antenna; (7) front tibia. All scales $=0.1 \mathrm{~mm}$ 
2.3. Remarks. As mentioned in the introduction, although in pronotal structure the new species resembles African Lycthoplites armatus Lesne, they are not related and belong to different tribes, so the similarity is evidently convergent: living in the same environment (wood) they developed similar morphological features, in this case the specifically formed pronotum facilitating extrication from wood. Interesting is also striking length of ovipositor, which may indicate that Trogoxylyctus gen. nov. lays eggs into external cracks of wood, not entering the galleries of other bostrichids as do representatives of related genera like Cephalotoma Lesne - also in this respect the new genus resembles those of Lyctini.

\subsection{Key to the identification of Australian species of the tribe Trogoxylini}

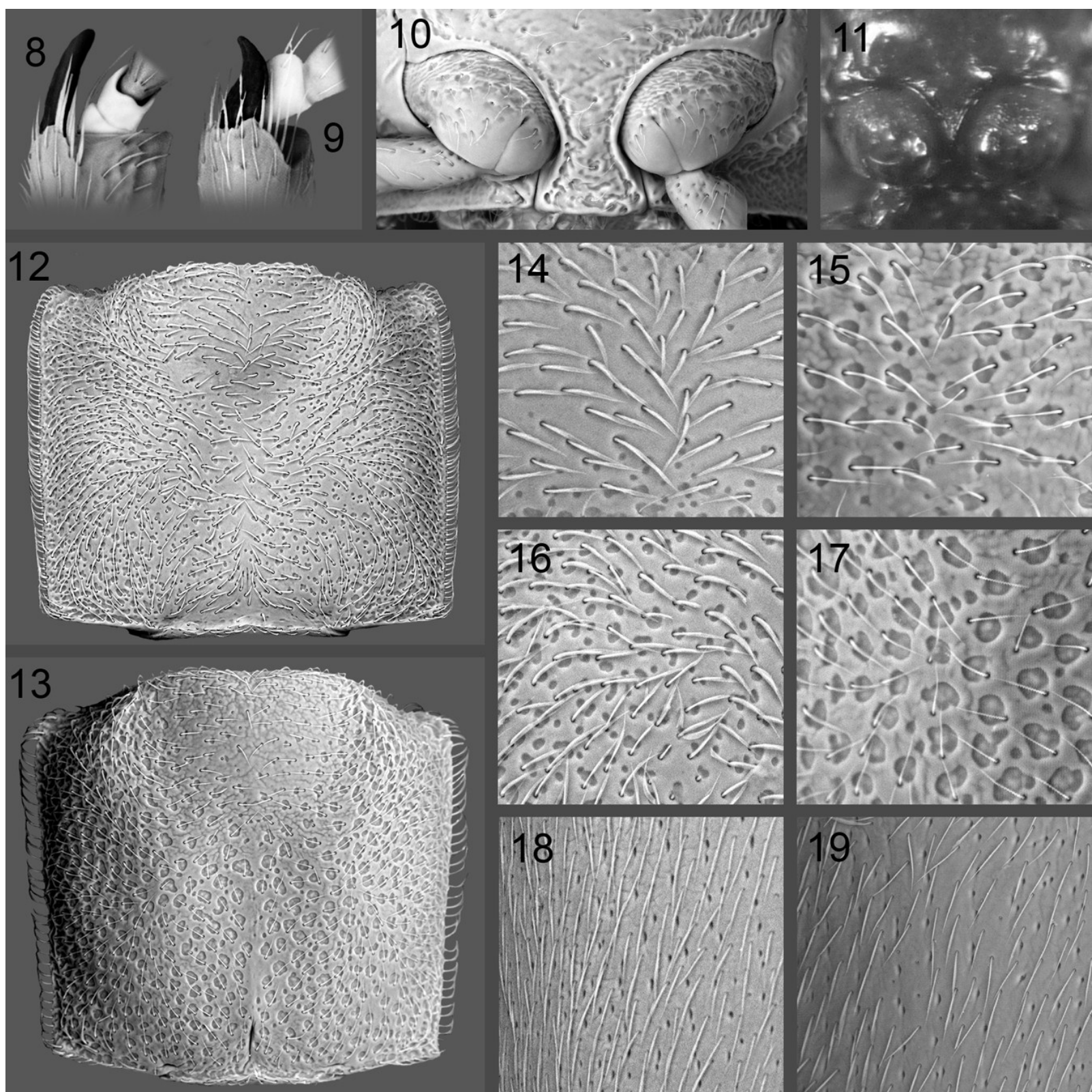

Figs. 8-19. Trogoxylini of Australia. 8 - Tristaria grouvellei Reitter; 9, 10 - Trogoxylon sp.; 12, 14, 16, 18 Trogoxylon ypsilon Lesne; 13, 15, 17, 19 - Trogoxylon punctipenne (Fauvel); 11 - Trogoxylyctus australiensis gen. nov., sp. nov. (8-9 - front tibia tips - dark colour indicates apical spur, light colour - first two tarsomeres; 10-11 - prosternum; 12-13 - pronotum; 14-15 - frontal surface, 16-17 - pronotal surface, 18-19 - elytral surface). 
1 Protibial spur conspicuous, large, arcuately curved, reaches at least to apex of second visible tarsomere (Fig.8).

Tristaria grouvellei Reitter

- Protibial spur inconspicuous, small, straight or slightly curved, reaches at most to apex of first visible tarsal joint (Fig. 9). .2 .

2 Prosternal process clearly visible, flattened, narrowed at midlength and distinctly widened to apex (Fig. 10). Trogoxylon LeConte 3.

- Prosternal process strongly narrowed towards apex where it appears as narrow sharp lamella (Fig. 11) Trogoxylyctus australiensis gen. et sp. nov. 3 Pronotum somewhat wider than long (Fig. 12); front and pronotum finely punctured (Figs 14 and 16). Pronotal and elytral surface lustrous, without microsculpture, finely and sometimes (especially on sides) densely setose (Figs 16 and 18).

Trogoxylon ypsilon Lesne

- Pronotum square or slightly longer than wide (Fig. 13); punctures of front and pronotum coarse (Figs 15 and 17). Pronotal and elytral surface mat, finely and densely microsculptured, covered with dense, silky, somewhat widened setae (Figs 17 and 19)

Trogoxylon punctipenne (Fauvel)

\section{References}

[1] Borowski, J. \& Węgrzynowicz, P. (2007) World Catalogue of Bostrichidae (Coleoptera). Mantis, Olsztyn. 247 pp., 8 plates.

[2] Borowski, J. \& Węgrzynowicz, P. (2012) The Powderpost Beetles of the World (Coleoptera: Bostrichidae). Volume I. Mantis, Olsztyn. 461 pp., 16 plates.

[3] Lawrence, J.F. \& Ślipiński, A. (2013) Loranthophila, a new genus of Australian Lyctinae (Coleoptera: Bostrichidae) associated with Mistletoe. Zootaxa, 3737: 295-300. 